\title{
Walking Speed Indoors and Outdoors in Healthy Persons and in Persons With Late Effects of Polio
}

\author{
Carin Willen ${ }^{\mathrm{a}, \mathrm{c}}$, Kirsten Lehmannn ${ }^{\mathrm{a}}$, Katharina S Sunnerhagen ${ }^{\mathrm{a}, \mathrm{b}}$
}

\begin{abstract}
Background: Walking speed tests are common means to screen physical ability and are usually performed in an institutional setting. Little additional information is normally given about the environmental circumstances. This study aimed to evaluate the effect of different environments on walking speed. The design is an observational study.
\end{abstract}

Method: Two groups (health controls and persons with late effects of polio) were studied, 30 meter walking test in convenient and maximal speed has been performed in 3 different environments.

Results: Both groups walked faster outdoors when compared with the indoor settings and the test order did not significantly influence this.

Conclusion: The findings from this study indicate that the traditional walking speed tests performed indoors may not be an optimal predictor of the walking speed outdoors. The Clinical Rehabilitation Impact is in rehabilitation.

Keywords: Polio; Mobility; Environment

\section{Introduction}

Walking ability is a basic prerequisite for many activities in

Manuscript accepted for publication April 22, 2013

${ }^{a}$ Institute of Neuroscience and Physiology, Section for Clinical Neuroscience and Rehabilitation Gothenburg University, Goteborg Sweden

bunnaas Rehabilitation Hospital and Faculty of Medicine, University of Oslo, Norway

${ }^{\mathrm{c} C}$ Corresponding author: Carin Willen, Institute of Neuroscience and Physiology/Physiotherapy Box 455, S-405 30 Goteborg, Sweden.

Email: carin.willen@gu.se

doi: http://dx.doi.org/10.4021/jnr187w human daily life. It is a complex behaviour which requires fine tuned coordination between many body systems. The ability to walk with a certain speed has shown to be critical for independent community life [1] and is influenced by individual factors as age, gender, body length and body weight $[2,3]$. Walking speed in elderly with and without mobility disorders has been studied in connection with other physical abilities and correlations with muscle strength $[4,5]$, sensory function [6], mobility and balance [7-9] as well as trunk posture [10] have been found.

Walking speed tests are common means to screen physical ability in persons with various diagnoses. Traditionally walking speed is tested indoors over 10 or 30 meters. These tests have shown validity and reliability [11]. They are usually performed in an institutional setting and little additional information is normally given about the environmental circumstances. The outdoor walking speed may not be investigated, probably due to inconvenience in the clinical work situation. However, walking speed is often assessed indoors and can be used in different statements regarding outdoor mobility.

Some reports about walking indoors versus walking outdoors and about environmental impact on gait have been published. Horemans et al [12] has shown good correlations between self preferred walking speed in a test situation and walking speed in daily life, measured with an ambulatory activity monitor. Values of distance walked showed no significant difference when Brooks et al [13] examined the relationship between indoor and outdoor 6-minute walk tests among individuals with chronic obstructive pulmonary disease on flat ground in moderate climate conditions. In other studies $[14,15]$ investigators conclude that walking speed is one among other risk factors for experiencing indoors or outdoors falls in community living elderly. The effect of the environment on gait characteristics in older women with and without neuropathy was studied by Richardson et al [16] who found that walking speed was reduced in both groups when the environment was more challenging. The role of the floor surface on walking speed in patients with stroke was investigated by Stephens and Goldie [17], who found that walking speed was significantly slower on carpet than on parquetry in this patient group. Values for walking speed 


\begin{tabular}{|c|c|c|c|c|c|c|}
\hline \multirow{2}{*}{ a } & \multicolumn{3}{|c|}{ Healthy } & \multicolumn{3}{|c|}{$\begin{array}{c}\text { Polio } \\
\text { (cohort II) }\end{array}$} \\
\hline & $\begin{array}{l}\text { Total }(\mathrm{h}) \\
\mathrm{n}=114\end{array}$ & $\begin{array}{l}\text { Men (h) } \\
n=52\end{array}$ & $\begin{array}{l}\text { Women (h) } \\
\mathrm{n}=62\end{array}$ & $\begin{array}{l}\text { Total }(\mathrm{p}) \\
\mathrm{n}=46\end{array}$ & $\begin{array}{l}\text { Men }(p) \\
n=17\end{array}$ & $\begin{array}{l}\text { Women }(\mathrm{p}) \\
\mathrm{n}=29\end{array}$ \\
\hline $\begin{array}{l}\text { Age } \\
\text { (years) }\end{array}$ & $\begin{array}{l}55.6(14.3) \\
31-84\end{array}$ & $\begin{array}{l}55.4(15.2) \\
32-84\end{array}$ & $\begin{array}{l}55.8(13.7) \\
31-83\end{array}$ & $\begin{array}{l}62.2(11.2) \\
32-80\end{array}$ & $\begin{array}{l}65.6(6.8) \\
53-78\end{array}$ & $\begin{array}{l}60.2(12.8) \\
32-80\end{array}$ \\
\hline BMI & $\begin{array}{l}24.5(3.2) \\
17.9-34.9\end{array}$ & $\begin{array}{l}25.6(3.2) \\
19.8-34.9\end{array}$ & $\begin{array}{l}23.6(3.0) \\
17.9-33.4\end{array}$ & $\begin{array}{l}25.8(4.0) \\
19.0-36.4\end{array}$ & $\begin{array}{l}25.6(3.3) \\
20.8-32.3\end{array}$ & $\begin{array}{l}25.9(4.3) \\
19.0-36.4\end{array}$ \\
\hline $\begin{array}{l}\text { Body } \\
\text { length } \\
\text { (cm) }\end{array}$ & $\begin{array}{l}172.5(9.7) \\
151-200\end{array}$ & $\begin{array}{l}180.1(7.2) \\
163-200\end{array}$ & $\begin{array}{l}166.0(6.4) \\
151-182\end{array}$ & $\begin{array}{l}169.1(8.4) \\
150-186\end{array}$ & $\begin{array}{l}177.1(6.4) \\
165-186\end{array}$ & $\begin{array}{l}164.3(5.2) \\
150-174\end{array}$ \\
\hline $\begin{array}{l}\text { Gait device } \\
\text { users (n) }\end{array}$ & - & - & - & 10 & 4 & 6 \\
\hline $\begin{array}{l}\text { Orthose } \\
\text { users (n) }\end{array}$ & - & - & - & 19 & 6 & 13 \\
\hline $\begin{array}{l}\text { Experience } \\
\text { of pain (n) }\end{array}$ & - & - & - & 20 & 10 & 10 \\
\hline
\end{tabular}

\begin{tabular}{|l|l|l|l|l|l|l|}
\cline { 2 - 7 } \multicolumn{1}{c|}{} & \multicolumn{3}{c|}{ Healthy } & \multicolumn{3}{c|}{$\begin{array}{l}\text { Polio } \\
\text { (cohort I } \\
\text { and II) }\end{array}$} \\
\cline { 2 - 7 } \multicolumn{1}{c|}{} & $\begin{array}{l}\text { Total (h) } \\
\mathrm{n}=114\end{array}$ & $\begin{array}{l}\text { Men (h) } \\
\mathrm{n}=52\end{array}$ & $\begin{array}{l}\text { Women (h) } \\
\mathrm{n}=62\end{array}$ & $\begin{array}{l}\text { Total (p) } \\
\mathrm{n}=96\end{array}$ & $\begin{array}{l}\text { Men (p) } \\
\mathrm{n}=38\end{array}$ & $\begin{array}{l}\text { Women (p) } \\
\mathrm{n}=58\end{array}$ \\
\hline $\begin{array}{l}\text { Age } \\
\text { (years) }\end{array}$ & $\begin{array}{l}55.6(14.3) \\
31-84\end{array}$ & $\begin{array}{l}55.4(15.2) \\
32-84\end{array}$ & $\begin{array}{l}55.8(13.7) \\
31-83\end{array}$ & $\begin{array}{l}61.0(11.1) \\
28-80\end{array}$ & $\begin{array}{l}63.8(9.7) \\
41-79\end{array}$ & $\begin{array}{l}59.1(11.7) \\
28-80\end{array}$ \\
\hline BMI & $24.5(3.2)$ & $25.6(3.2)$ & $23.6(3.0)$ & $26.3(4.3)$ & $26.0(3.7)$ & $26.4(4.7)$ \\
& $17.9-34.9$ & $19.8-34.9$ & $17.9-33.4$ & $19.0-42.3$ & $20.8-35.3$ & $19.0-42.3$ \\
\hline $\begin{array}{l}\text { Body } \\
\text { length } \\
\text { (cm) }\end{array}$ & $172.5(9.7)$ & $180.1(7.2)$ & $166.0(6.4)$ & $168.2(9.6)$ & $177.1(6.4)$ & $162.9(7.2)$ \\
\hline $\begin{array}{l}\text { Gait device } \\
\text { users (n) }\end{array}$ & - & - & - & 28 & $165-186$ & $145-177$ \\
\hline $\begin{array}{l}\text { Orthose } \\
\text { users (n) }\end{array}$ & - & - & - & 47 & 19 & 17 \\
\hline $\begin{array}{l}\text { Experience } \\
\text { of pain (n) }\end{array}$ & - & - & - & 47 & 19 & 28 \\
\hline
\end{tabular}

Figure 1. (a). Background data showing mean values, standard deviations (SD) and minimum-maximum values for the healthy group $(h)$ and the polio group $(p)$, cohort II, with gender subgroups, and characteristics for the polio group in number of persons. (b). Background data showing mean values, standard deviations (SD) and minimum-maximum values for the healthy group $(h)$ and the polio group $(p)$, cohort I and II, with gender subgroups, and characteristics for the polio group in number of persons.

(indoors) have been established for healthy individuals 20 79 years of age [18] and individuals in an urban population $40-79$ years [19]. In a study by Waters et al [20] walking speed values for level outdoor walking in convenient speed were determined for normal subjects in the ages between 20 and 80 years.

Many persons with a history of poliomyelitis are known to experience new symptoms of muscle weakness, pain, fatigue and decreased endurance many years after the acute polio onset [21-24], so called late effects of polio. The main functional problems in persons with late effects of polio include decreased walking ability, in particular slower walking speed and shorter stride length [24, 25]. For some benefits such as alternative transports, walking ability is asked for.
The purpose of this study was to evaluate the convenient and maximal walking speed indoors and outdoors in adult persons who were either healthy walkers or had late effects of polio. We hypothesized that walking indoors would be faster than outdoors.

\section{Methods}

\section{Subjects}

A total of 114 healthy walkers ( 62 women, 52 men) in the ages between $31-84$ years (mean age 55.2 years) were included as well as 96 persons with late effects of polio (58 


\begin{tabular}{|c|c|c|c|c|c|}
\hline & $\begin{array}{l}\text { Indoor quiet } \\
\text { conv }\end{array}$ & $\begin{array}{l}\text { Indoor quiet } \\
\max \end{array}$ & $\begin{array}{l}\text { Indoor busy } \\
\text { conv }\end{array}$ & $\begin{array}{l}\text { Indoor busy } \\
\max \end{array}$ & $\begin{array}{l}\text { Outdoor } \\
\text { conv }\end{array}$ \\
\hline $\begin{array}{l}\text { Healthy } \\
\text { group total } \\
\mathrm{n}=114\end{array}$ & $\begin{array}{l}\mathbf{1 . 4 8}(\mathbf{0 . 2 0}) \\
0.96-2.14\end{array}$ & $\begin{array}{l}2.11(\mathbf{0 . 3 6}) \\
1.49-3.66\end{array}$ & $\begin{array}{l}\mathbf{1 . 4 5}(\mathbf{0 . 2 1}) \\
1.04-1.99\end{array}$ & $\begin{array}{l}2.03(0.33) \\
1.41-3.12\end{array}$ & $\begin{array}{l}\mathbf{1 . 5 4}(\mathbf{0 . 1 9 )} \\
1.07-1.99\end{array}$ \\
\hline $\begin{array}{l}\text { Men } n=52 \\
\text { Women } n=62\end{array}$ & $\begin{array}{l}1.47(0.20) \\
1.50(0.20)\end{array}$ & $\begin{array}{l}2.19(0.47) \\
2.05(0.22)\end{array}$ & $\begin{array}{c}1.43(0.20) \\
1.47(0.22)\end{array}$ & $\begin{array}{l}2.09(0.42) \\
1.98(0.23)\end{array}$ & $\begin{array}{l}1.54(0.19) \\
1.54(0.20)\end{array}$ \\
\hline $\begin{array}{l}\text { 30-39 total } \\
\mathrm{n}=22\end{array}$ & $\begin{array}{l}\mathbf{1 . 4 9 ( 0 . 1 6 )} \\
1.18-1.76\end{array}$ & $\begin{array}{l}.30(0.37) \\
1.83-3.04\end{array}$ & $\begin{array}{l}\mathbf{1 . 4 8}(\mathbf{0 . 1 9 )} \\
1.13-1.79\end{array}$ & $\begin{array}{l}2.21(\mathbf{0 . 3 2}) \\
1.70-2.88\end{array}$ & $\begin{array}{l}\mathbf{1 . 5 9}(\mathbf{0 . 1 8}) \\
1.22-1.94\end{array}$ \\
\hline $\begin{array}{l}30-39 \\
\text { men/women } \\
n=12 / 10\end{array}$ & $\begin{array}{c}1.48(0.13) \\
/ \\
1.51(0.19) \\
\end{array}$ & $\begin{array}{c}2.42(0.42) \\
/ / \\
2.16(0.23) \\
\end{array}$ & $\begin{array}{c}1.47(0.20) \\
/ \\
1.50(0.19) \\
\end{array}$ & $\begin{array}{c}2.32(0.37) \\
/ \\
2.09(0.20) \\
\end{array}$ & $\begin{array}{c}1.61(0.20) \\
/ \\
1.56(0.16) \\
\end{array}$ \\
\hline $\begin{array}{l}\text { 40-49 total } \\
n=21\end{array}$ & $\begin{array}{l}\mathbf{1 . 6 0}(\mathbf{0 . 2 3}) \\
1.22-2.14\end{array}$ & $\begin{array}{l}2.31(0.43) \\
1.77-3.66\end{array}$ & $\begin{array}{l}\mathbf{1 . 5 2}(\mathbf{0 . 2 0}) \\
1.15-1.86\end{array}$ & $\begin{array}{l}2.20(0.38) \\
1.70-3.12\end{array}$ & $\begin{array}{l}\mathbf{1 . 6 0}(\mathbf{0 . 2 0}) \\
1.25-1.96\end{array}$ \\
\hline $\begin{array}{l}40-49 \\
\text { men/women } \\
n=10 / 11\end{array}$ & $\begin{array}{c}1.59(0.29) \\
/ \\
1.61(0.19) \\
\end{array}$ & $\begin{array}{c}2.46(0.54) \\
/ / \\
2.18(0.25) \\
\end{array}$ & $\begin{array}{c}1.49(0.19) \\
/ \\
1.55(0.21) \\
\end{array}$ & $\begin{array}{c}2.35(0.44) \\
/ / \\
2.07(0.27)\end{array}$ & $\begin{array}{c}1.57(0.23) \\
/ \\
1.63(0.19) \\
\end{array}$ \\
\hline $\begin{array}{l}\text { 50-59 total } \\
n=24\end{array}$ & $\begin{array}{l}\mathbf{1 . 5 4}(\mathbf{0 . 2 2}) \\
0.96-1.94\end{array}$ & $\begin{array}{l}\mathbf{2 . 1 8 ( 0 . 3 5 )} \\
1.80-3.49\end{array}$ & $\begin{array}{l}\mathbf{1 . 5 0}(\mathbf{0 . 2 0}) \\
1.10-1.92\end{array}$ & $\begin{array}{l}2.11(0.32) \\
1.72-3.06\end{array}$ & $\begin{array}{l}\mathbf{1 . 5 6}(\mathbf{0 . 1 9 )} \\
1.14-1.90\end{array}$ \\
\hline $\begin{array}{l}50-59 \\
\text { men/women } \\
n=9 / 15\end{array}$ & $\begin{array}{c}1.56(0.16) \\
/ \\
1.52(0.25) \\
\end{array}$ & $\begin{array}{c}2.33(0.51) \\
/ \\
2.09(0.18)\end{array}$ & $\begin{array}{c}1.53(0.18) \\
/ \\
1.48(0.23) \\
\end{array}$ & $\begin{array}{c}2.21(0.43) \\
/ \\
2.05(0.22) \\
\end{array}$ & $\begin{array}{c}1.58(0.15) \\
/ \\
1.56(0.21)\end{array}$ \\
\hline $\begin{array}{l}\text { 60-69 total } \\
n=21\end{array}$ & $\begin{array}{l}\mathbf{1 . 4 8}(\mathbf{0 . 1 5}) \\
1.30-1.82\end{array}$ & $\begin{array}{l}\mathbf{1 . 9 8 ( 0 . 1 8 )} \\
1.71-2.37\end{array}$ & $\begin{array}{l}\mathbf{1 . 4 7}(\mathbf{0 . 2 3}) \\
1.04-1.99\end{array}$ & $\begin{array}{l}1.94(0.18) \\
1.67-2.26\end{array}$ & $\begin{array}{l}\mathbf{1 . 5 6}(\mathbf{0 . 2 1}) \\
1.23-1.99\end{array}$ \\
\hline $\begin{array}{l}60-69 \\
\text { men/women } \\
n=9 / 12\end{array}$ & $\begin{array}{c}1.46(0.15) \\
/ \\
1.49(0.17) \\
\end{array}$ & $\begin{array}{c}1.98(0.22) \\
/ \\
1.98(0.15) \\
\end{array}$ & $\begin{array}{c}1.44(0.22) \\
/ \\
1.49(0.25) \\
\end{array}$ & $\begin{array}{c}1.92(0.24) \\
/ \\
1.95(0.14)\end{array}$ & $\begin{array}{c}1.52(0.23) \\
/ \\
1.58(0.19) \\
\end{array}$ \\
\hline $\begin{array}{l}70-79 \text { total } \\
n=22\end{array}$ & $\begin{array}{l}\mathbf{1 . 3 5}(\mathbf{0 . 1 4}) \\
1.09-1.69\end{array}$ & $\begin{array}{l}\mathbf{1 . 8 6}(\mathbf{0 . 1 5}) \\
1.49-2.17\end{array}$ & $\begin{array}{l}1.31(0.15) \\
1.08-1.67\end{array}$ & $\begin{array}{l}\mathbf{1 . 7 7 ( 0 . 1 8 )} \\
1.41-2.10\end{array}$ & $\begin{array}{l}\mathbf{1 . 4 4}(\mathbf{0 . 1 5}) \\
1.07-1.75\end{array}$ \\
\hline $\begin{array}{l}70-79 \\
\text { men/women } \\
n=9 / 13\end{array}$ & $\begin{array}{c}1.31(0.14) \\
/ \\
1.38(0.14)\end{array}$ & $\begin{array}{c}1.82(0.08) \\
/ \\
1.90(0.18)\end{array}$ & $\begin{array}{c}1.29(0.10) \\
/ \\
1.33(0.17)\end{array}$ & $\begin{array}{c}1.71(0.13) \\
/ \\
1.82(0.19)\end{array}$ & $\begin{array}{c}1.48(0.08) \\
/ \\
1.41(0.18)\end{array}$ \\
\hline $\begin{array}{l}\text { 80-84 total } \\
n=4\end{array}$ & $\begin{array}{l}\mathbf{1 . 2 6}(\mathbf{0 . 1 0}) \\
1.13-1.36\end{array}$ & $\begin{array}{l}\mathbf{1 . 6 6}(\mathbf{0 . 0 7}) \\
1.59-1.73\end{array}$ & $\begin{array}{l}1.24(0.18) \\
1.07-1.46\end{array}$ & $\begin{array}{l}\text { 1.61 (0.15) } \\
1.46-1.75\end{array}$ & $\begin{array}{l}\mathbf{1 . 3 5}(\mathbf{0 . 0 6}) \\
1.29-1.42\end{array}$ \\
\hline $\begin{array}{l}80-84 \\
\text { men/women } \\
n=3 / 1\end{array}$ & $\begin{array}{l}1.23(0.10) \\
/ \\
1.36\end{array}$ & $\begin{array}{l}1.68(0.08) \\
/ / \\
1.62\end{array}$ & $\begin{array}{l}1.17(0.12) \\
/ / \\
1.46\end{array}$ & $\begin{array}{l}1.66(0.13) \\
/ \\
1.46\end{array}$ & $\begin{array}{l}1.33(0.05) \\
/ / \\
1.42\end{array}$ \\
\hline
\end{tabular}

Figure 2. Results of the walking speed tests in the healthy group indoors on two locations and outdoors. Mean values, standard deviations (SD) and minimum-maximum values are given in $\mathrm{m} / \mathrm{s}$ for the whole group and for age cohorts. For gender subgroups mean values and standard deviations are presented.

women, 38 men) in the ages between 28 - 80 years. The latter are described in two cohorts I (mean age 62.2) and II (mean age 59.8).

Inclusion criteria in this study were for the healthy group: age between 30 and 85 , unimpeded walking ability indoors and outdoors and ability to understand instructions in Swedish. Exclusion criterion for the healthy group was any kind of physical condition that could impede walking. The healthy walkers were recruited either from the hospital staff, from relatives of patients at the clinic and from people living in the surrounding area of the hospital. Some of the people in the highest age categories ( 70 - 85 years) were recruited from a folk dancing association in the vicinity ( $\mathrm{n}=$ 12 out of 26 in this age group). The healthy walkers were consecutively tested from January 2005 to March 2006 (Fig. 1). They were invited to participate in the study by personal inquiry or by written announcements in and around the hospital area, resulting in phone contact with persons willing to participate. No person was excluded from the study.

Inclusion criteria for the polio group were: prior history of poliomyelitis with new symptoms appearing after a period of stable condition, functional walking ability with or without gait devices and/or orthoses and ability to understand instruction in Swedish. Exclusion criterion was any comorbidity that could influence walking ability. The persons with late effects of polio were recruited from the Polio clinic, Sahlgrenska University hospital. They were consecutively tested during the time from May 2005 to August 2006 (Fig. 1). The persons with late effects of polio were asked to participate by personal inquiry at their hospital visit. No person was excluded from the study.

The study was approved by the Ethics Committee, Uni- 


\begin{tabular}{|c|c|c|c|c|c|}
\hline & $\begin{array}{l}\text { Indoor quiet } \\
\text { conv }\end{array}$ & $\begin{array}{l}\text { Indoor quiet } \\
\max \end{array}$ & $\begin{array}{l}\text { Indoor busy } \\
\text { conv }\end{array}$ & $\begin{array}{l}\text { Indoor busy } \\
\max \end{array}$ & $\begin{array}{l}\text { Outdoor } \\
\text { conv }\end{array}$ \\
\hline $\begin{array}{l}\text { Polio group } \\
\text { Total } n=46\end{array}$ & $\begin{array}{l}1.13(\mathbf{0 . 2 3}) \\
0.70-1.54\end{array}$ & $\begin{array}{l}\mathbf{1 . 4 7}(\mathbf{0 . 3 5}) \\
0.79-2.20\end{array}$ & $\begin{array}{l}\mathbf{1 . 1 0}(\mathbf{0 . 2 1}) \\
0.66-1.55\end{array}$ & $\begin{array}{l}\mathbf{1 . 4 4}(\mathbf{0 . 3 3}) \\
0.80-2.22\end{array}$ & $\begin{array}{l}\mathbf{1 . 1 7}(\mathbf{0 . 2 5}) \\
0.59-1.61\end{array}$ \\
\hline $\begin{array}{l}\text { Polio group } \\
\text { men/women } \\
n=17 / 29\end{array}$ & $\begin{array}{c}1.17(0.27) \\
/ \\
1.11(0.21) \\
\end{array}$ & $\begin{array}{c}1.56(0.38) \\
/ \\
1.41(0.33) \\
\end{array}$ & $\begin{array}{c}1.13(0.22) \\
/ \\
1.09(0.22)\end{array}$ & $\begin{array}{c}1.51(0.35) \\
/ \\
1.40(0.31)\end{array}$ & $\begin{array}{c}1.25(0.26) \\
/ \\
1.12(0.24)\end{array}$ \\
\hline $\begin{array}{l}\text { 30-39 total } \\
n=3, \text { women }\end{array}$ & $\begin{array}{l}\mathbf{0 . 9 8}(\mathbf{0 . 2 2}) \\
0.76-1.20\end{array}$ & $\begin{array}{l}1.18(\mathbf{0 . 4 7}) \\
0.79-1.70 \\
\end{array}$ & $\begin{array}{l}\mathbf{1 . 0 2}(\mathbf{0 . 2 7}) \\
0.73-1.26\end{array}$ & $\begin{array}{l}1.24(0.47) \\
0.80-1.73\end{array}$ & $\begin{array}{l}\mathbf{0 . 8 7}(\mathbf{0 . 3 2}) \\
0.61-1.22 \\
\end{array}$ \\
\hline $\begin{array}{l}40-49 \\
n=0\end{array}$ & - & - & - & - & - \\
\hline $\begin{array}{l}\mathbf{5 0 - 5 9} \text { total } \\
n=14\end{array}$ & $\begin{array}{l}\mathbf{1 . 1 4}(\mathbf{0 . 2 2}) \\
0.80-1.54\end{array}$ & $\begin{array}{l}\mathbf{1 . 5 0}(\mathbf{0 . 3 3}) \\
1.05-2.20 \\
\end{array}$ & $\begin{array}{l}\mathbf{1 . 1 3}(\mathbf{0 . 2 1}) \\
0.70-1.51\end{array}$ & $\begin{array}{l}1.47(\mathbf{0 . 3 3}) \\
1.00-2.22 \\
\end{array}$ & $\begin{array}{l}\mathbf{1 . 1 6}(\mathbf{0 . 2 0}) \\
0.79-1.56 \\
\end{array}$ \\
\hline $\begin{array}{l}50-59 \\
\text { men/women } \\
n=4 / 10\end{array}$ & $\begin{array}{c}1.14(0.31) \\
/ \\
1.14(0.19)\end{array}$ & $\begin{array}{c}1.53(0.48) \\
/ \\
1.48(0.27)\end{array}$ & $\begin{array}{c}1.06(0.27) \\
/ \\
1.16(0.19)\end{array}$ & $\begin{array}{c}1.51(0.51) \\
/ \\
1.46(0.26)\end{array}$ & $\begin{array}{c}1.14(0.32) \\
/ \\
1.17(0.16)\end{array}$ \\
\hline $\begin{array}{l}\text { 60-69 total } \\
n=17\end{array}$ & $\begin{array}{l}\mathbf{1 . 1 5}(\mathbf{0 . 2 6}) \\
0.73-1.47\end{array}$ & $\begin{array}{l}\mathbf{1 . 5 3}(\mathbf{0 . 3 7}) \\
0.83-2.00\end{array}$ & $\begin{array}{l}\mathbf{1 . 1 1}(\mathbf{0 . 2 4}) \\
0.81-1.55\end{array}$ & $\begin{array}{l}\mathbf{1 . 4 9}(\mathbf{0 . 3 4}) \\
0.89-2.04\end{array}$ & $\begin{array}{l}1.23(0.25) \\
0.83-1.61\end{array}$ \\
\hline $\begin{array}{l}60-69 \\
\mathrm{men} / \text { women } \\
\mathrm{n}=8 / 9\end{array}$ & $\begin{array}{c}1.16(0.31) \\
/ \\
1.14(0.23)\end{array}$ & $\begin{array}{c}1.56(0.42) \\
/ \\
1.51(0.34)\end{array}$ & $\begin{array}{c}1.14(0.26) \\
/ \\
1.09(0.24)\end{array}$ & $\begin{array}{c}1.49(0.37) \\
/ \\
1.49(0.33)\end{array}$ & $\begin{array}{c}1.28(0.29) \\
/ \\
1.18(0.22)\end{array}$ \\
\hline $\begin{array}{l}\text { 70-79 total } \\
n=10\end{array}$ & $\begin{array}{l}\mathbf{1 . 1 6}(\mathbf{0 . 2 3}) \\
0.70-1.39\end{array}$ & $\begin{array}{l}\mathbf{1 . 4 5 ( 0 . 3 6 )} \\
0.83-1.97\end{array}$ & $\begin{array}{l}1.13(0.21) \\
0.66-1.37\end{array}$ & $\begin{array}{l}\mathbf{1 . 3 9}(\mathbf{0 . 3 3}) \\
0.83-1.87\end{array}$ & $\begin{array}{l}\mathbf{1 . 1 9}(\mathbf{0 . 2 8}) \\
0.59-1.46\end{array}$ \\
\hline $\begin{array}{l}70-70 \\
\text { men/women } \\
n=5 / 5\end{array}$ & $\begin{array}{c}1.22(0.18) \\
/ \\
1.09(0.28)\end{array}$ & $\begin{array}{c}1.61(0.30) \\
/ \\
1.31(0.38)\end{array}$ & $\begin{array}{c}1.18(0.12) \\
/ \\
1.07(0.28)\end{array}$ & $\begin{array}{c}1.54(0.26) \\
/ \\
1.24(0.35)\end{array}$ & $\begin{array}{c}1.28(0.19) \\
/ \\
1.10(0.35)\end{array}$ \\
\hline $\begin{array}{l}\text { 80-84 total } \\
n=2, \text { women }\end{array}$ & $\begin{array}{l}\mathbf{0 . 9 8}(\mathbf{0 . 0 6}) \\
0.94-1.02\end{array}$ & $\begin{array}{l}\mathbf{1 . 2 9}(\mathbf{0 . 0 5}) \\
1.25-1.32 \\
\end{array}$ & $\begin{array}{l}\mathbf{0 . 9 5}(\mathbf{0 . 0 2}) \\
0.93-0.96\end{array}$ & $\begin{array}{l}\mathbf{1 . 3 1}(\mathbf{0 . 0 1 )} \\
1.31-1.32 \\
\end{array}$ & $\begin{array}{l}\mathbf{0 . 9 9}(\mathbf{0 . 0 8}) \\
0.94-1.04 \\
\end{array}$ \\
\hline
\end{tabular}

Figure 3. Results of the walking speed tests in the polio group indoors on two locations and outdoors. Mean values, standard deviations (SD) and minimum-maximum values are given in $\mathrm{m} / \mathrm{s}$ for the whole group and for age cohorts. For gender subgroups mean values and standard deviations are presented.

versity of Gothenburg, Sweden. Written informed consent was obtained from all participants.

\section{Assessments}

Walking speed was tested as presented by Witte et al [11] for convenient and maximal speed over 30 meters. A digital clock was used. The steps the person used for each 30-meter test were counted. The indoor test locations were: a) busy location: the corridor in the physiotherapy department with doors, technical devices and openings to adjacent rooms and with patient and staff moving around, b) quiet location: an empty corridor in the basement without disturbances. The two indoor corridors had the same regular wall-to-wall plastic carpet with an even surface, well kept, and well lit. The busy location was brighter lit up.

The outdoor test location consisted of a pedestrian passway in a garden. The outdoor walkway was made of concrete tiles $(45 \times 45 \mathrm{~cm})$, which presented a somewhat uneven surface, but no slopes or curbs were present. In the winter time there was at times snow, ice and gravel on this surface, and sometimes the width of the pass-way was narrowed due to snow banks. The clinical setting, basement setting, and outdoor setting widths were 2.6, 2.7, and $4 \mathrm{~m}$ respectively. In each environment, a known distance $(30 \mathrm{~m})$ was marked.

For cohort I the tests were performed indoors (a) and outdoors in the same order, For cohort II and the healthy walkers the tests were performed on two locations indoors (a + b) and on one occasion outdoors in a randomized order. The outdoor temperature, wind velocity and direction of the wind were noted using continuously updated information from a local internet weather station; Goteborg REAB; www.reab. se. The outdoor ground surface condition was noted.

All persons were wearing their ordinary shoes and outdoor clothes as preferred. The persons with late effects of polio used the orthoses and/or gait devices they would use elsewhere in similar situations if appropriate. All persons were assured at least 1 minute resting time between the tests, more if requested.

\section{Statistics}

Conventional formulas for the calculation of mean and standard deviation (SD) of continuous variables and median and range of non-continuous variables were used. Differences within and between groups were analyzed using non parametric tests, Wilcoxon Signed Rank test (within groups) and Mann-Whitney test (between groups). A linear multiple regression model was used to test the influence of sex, age and weather conditions. A one-way repeat measures analysis was used to analyze the results of the $30 \mathrm{mWT}$ in three different environments. 
Analyses were performed using the SPSS computer package (Version 15.0).

\section{Results}

The values for the separate tests in different ages for the healthy persons are shown in Figure 2 and for the polio group in Figure 3. Both groups walked significantly faster $(\mathrm{P}<000$ to 0.001 ) in the outdoor locations when compared with the two indoor settings. Age, sex or weather conditions did not influence the outdoor gait speed. There were significant differences between the values for walking in a quiet compared with a busy indoor setting for both groups, with the higher speed results in the quiet location.

One-way repeat measures analysis was conducted to explore the influence of the test-order on the walking performance in the different environments. There was a significant effect on the convenient speed from the environment (Wilk's lambda $=0.24, \mathrm{~F}(10,306)=31.96, \mathrm{P} \leq 0.001$, partial eta square $=0.51)$. There were no statistical meaningful effect for test order $(F 5,154)=0.35, \mathrm{P}=0.88)$. For maximal speed there was also a significant effect of environments (Wilk's lamda $=0.82, \mathrm{~F}(10,306)=3.13, \mathrm{P} \leq 0.001$, partial eta square $=0.09$ ). There were no statistical meaningful effect for test $\operatorname{order}(\mathrm{F} 5,154)=1.39, \mathrm{P}=0.23)$.

\section{Discussion}

The aim of this study was to evaluate the convenient and maximal walking speed indoors and outdoors in adult persons who were either healthy walkers or had late effects of polio. The results showing significantly higher outdoor walking speed in both groups and that this could not be explained by the test order were somewhat astonishing to us, as the assumption had been that outdoor walking would be more challenging.

The healthy walkers in this group had a somewhat faster convenient walk than the values reported from Bohannon [18] as well as Waters [20]. There are some differences in the design of the walking tests. Bohannon [18] had the person timed while walking $7.62 \mathrm{~m}$ ( 25 feet $)$ with a "running start". In this study, the persons where timed when they started to walk and the timer was stopped after $30 \mathrm{~m}$ when they crossed the second line. This means that in the present study, an acceleration period is part of the test. However, the maximum test was lower in our study regardless of busy or quiet corridor. If we compare the results from the outdoor walking with those of Waters et al [20], again the test procedures differ. Waters et al assess oxygen costs while walking outdoors, with the persons walking around a track $(60.5 \mathrm{~m}$ in circumference) carrying a modified Douglas bag. Their young subjects (20 - 59 years of age) walked slower (1.33 $\mathrm{m} / \mathrm{s}$ ) compared to our results for the whole group $(1.54 \mathrm{~m} / \mathrm{s})$. The explanation for the difference in speed is probably mainly due to the discomfort of the Douglas bag.

For us as well as for the person in the polio group, the fact that they managed to walk faster outdoors even in cold weather with snowy, slippery ground conditions, compared with the indoor walking speeds was a surprise. Some of the persons were not at all aware of that they actually had walked faster outdoors; their feeling had been that it had been the most exhausting test (independent of in which order the outdoor test had been accomplished).

Several attempts to explain the faster outdoor speed have been proposed by the study persons themselves, when presented with their individual walking results after each session: 1). Outdoors you feel freer and the air is fresh which makes it easier to move. 2). If it is cold outside which makes you eager to walk faster to get inside again, or to get warm from the stronger body movement. 3). Outdoors is "everyone's" environment, you are not restricted to an unknown and perhaps frightening hospital setting.

In addition we propose that the persons in both groups may have felt less concern about possible interfering incidents (namely, persons appearing, doors opening) outdoors, which also may explain the faster speed results in the quiet indoor location compared to the busy indoor location.

\section{Limitations}

In this study we chose three different environment locations in the hospital area. The conclusions are taken from our result data in these special locations and may not be true for other locations. The outdoor location was somewhat uneven but straight and might not have been very challenging (except in snowy conditions). The oldest healthy study persons were recruited from a selected group of possibly very physically active elderly people, as they were all members of a dancing society. They may not have been altogether representative for the general population of elderly people in the community.

The walking speed test over 30 meters outdoors may be too short a distance to really state a person's ability to walk with sufficient speed to participate in the community under different environmental conditions and for every day purposes; as moving to and from a parking lot, bus stop, in a shopping mall etc. If the test distance would have been longer the results of this study, concerning at least the polio group, may have resembled the findings by Brooks et al [13], showing no significant difference between outdoor and indoor walking ability.

\section{Clinical rehabilitation impact}

The findings from this study indicate that the traditional walking speed tests performed indoors may not be an opti- 
mal predictor of the walking speed outdoors.

\section{References}

1. Lundgren-Lindquist B, Aniansson A, Rundgren A. Functional studies in 79-year-olds. III. Walking performance and climbing capacity. Scand J Rehabil Med. 1983;15(3):125-131.

2. Samson MM, Crowe A, de Vreede PL, Dessens JA, Duursma SA, Verhaar HJ. Differences in gait parameters at a preferred walking speed in healthy subjects due to age, height and body weight. Aging (Milano). 2001;13(1):16-21.

3. Himann JE, Cunningham DA, Rechnitzer PA, Paterson DH. Age-related changes in speed of walking. Med Sci Sports Exerc. 1988;20(2):161-166.

4. Willen C, Sunnerhagen KS, Ekman C, Grimby G. How is walking speed related to muscle strength? A study of healthy persons and persons with late effects of polio. Arch Phys Med Rehabil. 2004;85(12):1923-1928.

5. Rantanen T, Era P, Heikkinen E. Maximal isometric strength and mobility among 75-year-old men and women. Age Ageing. 1994;23(2):132-137.

6. van Wezel BM, van Engelen BG, Gabreels FJ, Gabreels-Festen AA, Duysens J. Abeta fibers mediate cutaneous reflexes during human walking. J Neurophysiol. 2000;83(5):2980-2986.

7. Rantanen T, Guralnik JM, Ferrucci L, Penninx BW, Leveille S, Sipila S, Fried LP. Coimpairments as predictors of severe walking disability in older women. J Am Geriatr Soc. 2001;49(1):21-27.

8. Montero-Odasso M, Schapira M, Varela C, Pitteri C, Soriano ER, Kaplan R, Camera LA, et al. Gait velocity in senior people. An easy test for detecting mobility impairment in community elderly. J Nutr Health Aging. 2004;8(5):340-343.

9. Lehmann K, Sunnerhagen KS, Willen C. Postural control in persons with late effects of polio. Acta Neurol Scand. 2006;113(1):55-61.

10. Hirose D, Ishida K, Nagano Y, Takahashi T, Yamamoto $\mathrm{H}$. Posture of the trunk in the sagittal plane is associated with gait in community-dwelling elderly population. Clin Biomech (Bristol, Avon). 2004;19(1):57-63.

11. Witte US, Carlsson JY. Self-selected walking speed in patients with hemiparesis after stroke. Scand J Rehabil Med. 1997;29(3):161-165.

12. Horemans HL, Bussmann JB, Beelen A, Stam HJ, Nollet F. Walking in postpoliomyelitis syndrome: the rela- tionships between time-scored tests, walking in daily life and perceived mobility problems. J Rehabil Med. 2005;37(3):142-146.

13. Brooks D, Solway S, Weinacht K, Wang D, Thomas S. Comparison between an indoor and an outdoor 6-minute walk test among individuals with chronic obstructive pulmonary disease. Arch Phys Med Rehabil. 2003;84(6):873-876.

14. Bergland A, Jarnlo GB, Laake K. Predictors of falls in the elderly by location. Aging Clin Exp Res. 2003;15(1):4350.

15. Bath PA, Morgan K. Differential risk factor profiles for indoor and outdoor falls in older people living at home in Nottingham, UK. Eur J Epidemiol. 1999;15(1):65-73.

16. Richardson JK, Thies SB, DeMott TK, Ashton-Miller JA. A comparison of gait characteristics between older women with and without peripheral neuropathy in standard and challenging environments. J Am Geriatr Soc. 2004;52(9):1532-1537.

17. Stephens JM, Goldie PA. Walking speed on parquetry and carpet after stroke: effect of surface and retest reliability. Clin Rehabil. 1999;13(2):171-181.

18. Bohannon RW. Comfortable and maximum walking speed of adults aged 20-79 years: reference values and determinants. Age Ageing. 1997;26(1):15-19.

19. Sunnerhagen KS, Hedberg M, Henning GB, Cider A, Svantesson U. Muscle performance in an urban population sample of 40- to 79-year-old men and women. Scand J Rehabil Med. 2000;32(4):159-167.

20. Waters RL, Hislop HJ, Perry J, Thomas L, Campbell J. Comparative cost of walking in young and old adults. $\mathrm{J}$ Orthop Res. 1983;1(1):73-76.

21. Halstead LS, Rossi CD. New problems in old polio patients: results of a survey of 539 polio survivors. Orthopedics. 1985;8(7):845-850.

22. Cosgrove JL, Alexander MA, Kitts EL, Swan BE, Klein MJ, Bauer RE. Late effects of poliomyelitis. Arch Phys Med Rehabil. 1987;68(1):4-7.

23. Grimby G. Symptoms, disability, muscular structure and function, and electromyographic evaluation of post-polio individuals at 4-5 years of follow-up. Disabil Rehabil. 1996;18(6):306-307.

24. Willen C, Grimby G. Pain, physical activity, and disability in individuals with late effects of polio. Arch Phys Med Rehabil. 1998;79(8):915-919.

25. Perry J, Mulroy SJ, Renwick SE. The relationship of lower extremity strength and gait parameters in patients with post-polio syndrome. Arch Phys Med Rehabil. 1993;74(2):165-169. 